\title{
The Main Features of Semantic Approach of Polysemy
}

\section{Sonila Daiu}

University of Tirana

\author{
Doi:10.5901/jesr.2015.v5n3p169
}

\begin{abstract}
In linguistic, polysemy is a phenomenon of language not of speech. In this article the main focus is in understanding polysemy from semantic point of view in schools, colleges or university context. Treated together with homonymy both represent quite complex linguistic phenomena, which deserves proper treatment. This article addresses to four main features of polysemy that not only can help us understand the actual meaning of a word, but also to distinguish it from homonymy. How to up-hold these features unswervingly is demonstrated through giving details and using all the time a comparative approach and illustrating them with relevant examples from both English and Albanian languages. This article aims to raise language teacher's awareness of the significance of semantic approach of polysemantic words and eventually aid them with a valid, practical and useful tool in their everyday teaching process.
\end{abstract}

Keywords: polysemy, homonymy, polysemantic word, diachronic, synchronic, lexical semantic polysemy, etymology

\section{Introduction}

The study of semantic movements finds it impossible not to include matters of polysemy. "Polysemy study is of fundamental importance to any inquiry study into the semantic structure of a language" (Herrman, 2003,p.349). This for the main reason that semantic transformation do not mean simply replacing meaning with another one ,but a growing number of meanings within the semantic structure of a word. While older meanings may have a limited use or they may disappear entirely.

Coexistence of semantic components constitutes a linguistic reality which exists more in linguistic competence of speakers, as part of the language system, rather than in his linguistic performance, during the discourse. Each speaker of a language selects automatically the proper variant, helped of course by the context (linguistic or non-linguistic).

So, polysemy as etymology of the word itself suggests, is the ability of linguistic sign to have more meanings synchronically (Memushaj, 2006,p.168). This does not mean that polysemy is only a phenomenon, which is studied only in synchronic level, on the contrary, it can be studied even in the diachronic level.

Polysemy study seen from diachronic approach is regarded as the development and change of semantic structure of the word: a word can save its previous meanings and at the same time, arises and develops new meanings. Diachronic study of polysemy examines the interdependence and connection that exists between the individual meanings of a polysemantic word, which are the primitive and derivate words and how are the meanings related to each - other.

Seen in synchronic approach, polysemy means the coexistence of different meanings in a period of historical development of a language. Here is taken into consideration all the semantic structure of the word, the place that each meaning takes in this structure, the way in which they appear in the dictionary, even the weight of importance of each semantic component. The importance of a semantic component can be determined depending on the frequency of their use. The main meaning and most important appears more in use than other semantic components.

Being too complicated, even the polysemy concept presents more challenges of lexical semantic, as for example determining the number of meanings, transfers of meaning and difficulties that represents the difference between polysemy and homonymy.

\section{Sources of Polysemy}

Separation of meanings is more relative. "The rate of approaching and recession of the meanings from each - other, the rate of their recognition and type of dictionary which distinguishes the meanings of a polysemantic word, make that borders between meanings of a given word not to be punctual and checked (Thomai, p. 129). Through comparing dictionaries in different periods is clearly seen that the same words have different meaning quantity. This ambiguity of 
meaning (Ravin,2000, p.2 includes not only the different semantic components of the word but also aspects of semantic differences within the same meaning or semantic component. For example, in English, the word child or cousin, not clearly defined word's gender and during their use in sentence, come out two possible meanings of this word.

\section{Ashley went to meet her cousin.}

(Eshli shkoi për vizitë te i afërmi i saj. )

But exist also the case where meanings of one lexeme are not only those which exits in the dictionary. For example the verb ha (eat ) -1. Përtyp dhe kapërdij diçka për tu ushqyer (to put food into your mouth and swallow it)- ; within this meaning we may distinguish some different variety of meaning. So, when we say ha arra (eat nuts ) dhe ha supën ( eat soup ) in the first action we use only our fingers, while in the second action we use the spoon, but simply we drink it because it is liquid; or ha portokall ( eat an orange ) dhe ha mollë ( eat an apple ) the first meaning may sometimes be only liquid suction, while the second meaning chewing the fruit. Therefore, the verb ha- eat must have different meanings for each type of food we use or the semantic field of the verb - ha (eat) may have an overlapping with semantic field of the word pi -(drink) (Jackson, 2007, p.70).

Thereby, a word must have its primary meaning, but we can talk about a transfer of meanings, like in the above example or in the case of metaphor "Birth of a new meaning of a word generally passes through a comparison. The way is: from comparison to metaphor, from metaphor in lexicon, when it starts to lose emotional connotation, when it becomes a general use, sustainable and compulsory for language speakers" (Thomai J , 2006, p. 126). This approach highlights once more the difficulty of determining the exact number of meanings that a word can have. For example, the word prush -( ember) - grumbull thëngjijsh të ndezur, por pa flake we have the emergence of a new meaning, comparing not only the physical appearance but also the feeling that causes ishte bërë prush me vaporet; or in figurative way for the intensity of feelings or desires we have prushi i dashurisë; moreover we find comparisons of the new meanings : është prush i nxehtë, or e kishte shtëpinë prush me fëmijë; and here we mention new meanings arising from the use of this word in various phraseological expressions as : është saç pa prush, vë dorën në prush, e do si prushin në gji etc..

One of the most troubling consequences that this uncertainty of semantic component causes, is ambiguity, as a result of various readings that these variants cause. Numerous examples to illustrate this argument are presented by Cruse, where he deals with ambiguity, and some of its sources and the role that context plays in the selection, restriction and adoption of semantic variants (Cruse, 1986, p. 61). As in the following sentence in which the word position - pozicion depending on context can be used to indicate the location of someone or someone's position in relation to a particular issue.

A. Has Peter changed his position?

i. Yes, he is now sitting next to the judge.

ii. No, he still supports death punishment.

Also in Albanian we found the examples as follows:

- Po xhanëm, ti e bitise punën tënde që kur e mbarse, e tashti na e lë neve të heqim barren. ( J. Xoxe, "Lumi i vdekur", fq.25)

Since, that polysemantic words are one of the causes of the ambiguity some scholars like Aristotel have been critical on it, saying that ambiguous words are used mainly to mislead the listeners. Since then, philosophers have called polysemy a shortage of language and as a major obstacle to communication. All these views were dismissed by Breal, under which ambiguity was an indicator of the superiority of one language. The expansion of the semantic structure of word, is vocabulary enrichment and one of the internal ways of the expressional and communicational growth of language. Words used in a speech are related to other words and thus create contexts within which every word builds only one of its meanings (Thomai J. , Leksikologjia e Gjuhës Shqipe, p.129). Later, polysemy began to be studied under the light of etymology, lexicography and historic semantic. On the other hand, different scholars like Lici, Laisen, and Lipka studied the polysemy phenomenon, focusing on the difference between polysemy and homonymy.

However, the study of polysemy from cognitive linguistic (Croft, 2004 , p.109 - 140)brought a new approach in the study of the meaning, cognitive processes and existing experience in the study of language. This approach toward polysemy was based in new theories related the definition of the categories on the basis of prototypes where semantic components are related to each - other focusing on cognitive principles like metaphor, generalization and specialization. The relation between them is like a relationship network in radial shape, the advantage lies in the connection that all semantic components have with the primary meaning. Even though meanings are not always related directly with the 
primary meaning, like we have seen in the examples above, again they remain connected with that meaning through semantic node, which traverses all possible meanings of a word.

Consequently, within the context of cognitive approach, the difference between polysemy and homonymy was based in the systematic relations of meanings within polysemy.

According to these researchers, the meanings of polisemantic words are related with each - other in systematic and natural way, creating in this way a radial category, where one or more are prototypical than the others (Lakoff, 1987. p. 418 - 439).

Let us illustrate with an example:

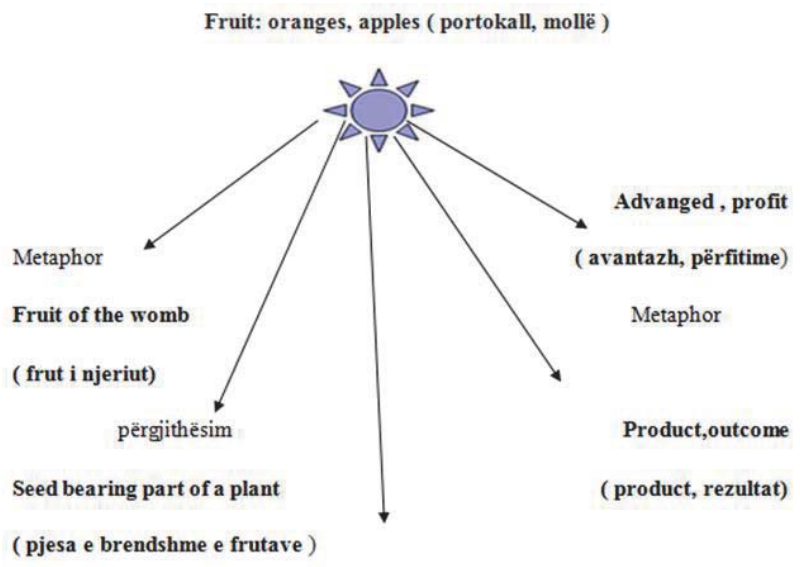

përgïthësim

Fruits of the earth

(produkte të tokës)

Picture 1. The semantic relation of meanings (Geerarests, 2010, p.195)

Another aspect of cognitive analyses toward polysemy is that of the study which was done beyond the lexical plan and was considered the organizing principle of other linguistic levels, like morphology, phonology and syntax. Even though, we must say that polysemy is more a conceptual category rather than linguistic one. It appears in a systematic manner in all levels of language, that we can identify a lot of common things between lexical, morphological and syntax organization.

Furthermore, in relation to the causes of polysemy are posed different hypothesis, as the mismatch of language and thought, linguistic economy, the disproportion between limited number of linguistic signs and endless character of human experience etc.. But a main factor which prohibits the clear appearance of polysemy is the relation with features of human recognition. In this process of recognition, we approach to the new one, based on the previous experiences, from the known we go to the unknown, from the concrete to the abstract and in every step of this process is done with the language help, and for the new things we usually use the existed labels.

\section{Cases How Polysemy Was Created}

Well, polysemy is an essential feature of the language and the causes of her existence in the language can be summarized as follows:

The same word takes different meanings and use. Since the same word carries different aspects which can be used from the context, some of this new meanings that the word takes are temporary or are changed into permanent semantic nuances and as they move away from each - other, we consider them as different meanings of the same word. Even though this phases of development of new meanings are written and identified in dictionaries, in reality they are imperceptible and undifferentiated. In English, the adjective handsome throughout its use has had this meanings as 
follows:

People: 1. I aftë, i zgjuar; 2. I përshtatshëm, si duhet, i duhuri; 3. I bukur me dinjitet

Size/Amount: 1. Mesatarisht e madhe; 2. Mjaftueshëm, tepër bujar

Action /discourse: 1. E përshtatshme, e duhur, me zgjuarsi

Behavior: 1. E duhur, e përshtatshme; 2. Fisnike, me trimëri; 3. Bujare, zemërgjerë

All these meanings have come from the use of the word in different contexts, and also in its figurative use. Nowadays, the adjective handsome is used only in three meaning which have survived respectively "i, e bukur", "bujar (e )" and "mjaftueshëm".

Specific meanings based on usage field. Polysemy appears because in every situation, in every profession, every word takes a specific use. So the word letër (paper) do not refer only to the material, but it may refer to a legal document: newspaper, the questions in a test, in plural it refers to identification documents etc..

Figurative meaning of the word. We have approach beforehand the metaphor and other linguistic figurative form, as important factors in meaning motivation, but at the same time for the positive and negative connotations the meaning has. A word can take more than one figurative meaning, but never losing the primary meaning; for examples: kujtime të mjegullta, e shkon jetën mjaltë, e kam kokën plumb, time is money, he has a heart of stone, eye of the law.

Lexical borrowings. Great effects in creation of new meanings have also the borrowings.

In this case, can be borrowed a word as phonetic complex together with the proper meaning, such as borrowings from Greek or Latin, in English and in Albanian : symbol, synonym, phonology. Or may be borrowed the foreign meaning, in the cases where we do not have a local word and can happen that the borrowed meaning replaces the existed meaning. For example, in English language, specific meanings of the words, propoganda, reactions in political field were provided from French impact. Semantic borrowing happens generally between those languages that have a strong relation with each - other and where one serves as a model for the other. Good examples can be seen in mutual borrowings of English and American as : homely - "e zakonshme, familjare, e rehatshme"; except these meanings this word in American english is used with the meaning "e shëmtuar" ose " tardy" - "i vonuar ", in British English this word is used for those people who have mental problems, in American English is used for someone who comes late in school. In Albanian language we see a new meaning of the adjectives i majtël i djathtë borrowed in relation to political meaning.

$\mathrm{Re}$-interpretation of homonymy. In the same way as homonymy is created from isintegration of polysemy, there exist cases where polysemy is created from homonymy. So, for those words which have not had any visible semantic difference between them, but have been the same from the phonetic side, speakers of a language are inclined to consider them as single word with different meanings. Based on diachronic aspect, we are dealing with the phenomenon of homonymy, because we have different etymology sources.

On the other hand, in synchronic aspect, where the discourse is developed, we never think of the words etymology, but we are keen to establish a connection based on psycological identity rather than linguistic one. This kind of polysemy is quite rare, consequently examples given might not be categorical, because they are based on subjective attitudes of a language speaker, if considering these meanings as two different words or different semantic variants of the same word. For example, the word corn, one of the meanings is misër ; the etymology of this meaning may be searched in old English, while the other meaning kallo comes from old French. From the physical similarity, both meaning are considered as polysemantic meanings of the same word corn. This phenomenon is known as folk etymology which serves as the basis for the classification of a lot of polysemantic meanings as part of homonymy within a language.

\section{Conclusion}

Although, the latest studies concerning semantic changes have claimed that they have an only direction, are regular and repeated not only in a certain time but at all times of the language development and in different languages. Their existence in synchronic level and in different languages is related to several factors, primarily with cognitive and communicative process where pragmatic meanings are conventionalized and re-analyzed as polysemantic meaning. The extension of word semantic structure is the so called polysemantic development.

Semantic structures of words in Albanian language as well as in English one change and expand in an unlimited number of meanings. There are times when the birth of new meanings pushes the old ones to the structure edges, the semantic thread which holds these meanings related, being stretched so much starts to disconnect creating in this way a new lexical unit and consequently semantic one. Keeping this in mind, we have tried and made an attempt to group the 
main sources of polysemy, giving details and using all the time a comparative approach and illustrating them with relevant examples from both languages to give some valuable insights in terms of this so - much debated distinction.

\section{References}

Croft, W and Cruse, A. D ( 2004), Cognitive Linguistics, Cambridge University Press, pg 109 - 140

Cruse, A. D. (1986), Lexical semantics, Cambrige University Press, pg 61

Lakoff, G. ( 1987 ), Women, Fire and dangerous things: What Categories Reveal about Mind ? University of Chicago Press pg. 418 439

Memushaj, R.( 2006 ), Hyrje në Gjuhësi, Botimet Toena, pg 168

Memushaj, R.( 2006 ), Hyrje në Gjuhësi, Botimet Toena, pg 172

Nerlich, B , Zazie, T. Dhe Clarke, D.D. (2003),Emerging patterns and evolving polysemies: the acquisition of get between four and ten years. In Nerlich, B, Zazie, T,

Herrman,V. And Clarke, D.D. (eds.), Polysemy : flexible patterns of meaning in mind and language, Mounton de Gruyter, pg. 349

Jackson, H. and Amwela, Z. E (2007), words, Meanings and Vocabulary. An Introduction to Modern English Lexicology, Atheneum Press, pg. 70

Ravin, Y. and Leacock, C . (2000), Polysemy : An Overview to Polysemy, Theoretical and Computational Approches, edited by Ranvin, Y. and Leacock, $\mathrm{C}$.

Oxford University Press pg. 2

THomai, J. ( Leksikologjia e Gjuhës Shqipe, Botimet Toena, pg. 129

Thomai, J. (2006), Leksikologjia e Gjuhës Shqipe, Botimet TOENA, Pg. 126

Thomai, J. ( 2006), Leksikologjia e Gjuhës Shqipe, Botimet TOENA, Tirane pg. 129 
